\title{
Relation Between Religion and Social Integration Toward Multicultural Community of Dayak Halong
}

\author{
Moh. Zaenal Arifin Anis \\ History Department \\ Faculty of Teacher Training and Education \\ Universitas Lambung Mangkurat \\ Banjarmasin Indonesia \\ mzarifinanis@yahoo.co.id
}

\author{
Deasy Arisanty \\ Geography Study Department \\ Faculty of Teacher Training and Education \\ Universitas Lambung Mangkurat \\ Banjarmasin, Indonesia \\ deasyarisanty@unlam.ac.id
}

\begin{abstract}
Study of interreligious relationships can build social integration is still interesting to be discussed. This paper dissects social relations between religions through a qualitative approach. The results of this study inform that interreligious relationships built on the pride of primordial identity as Dayak Halong. People have prioritized for kinship, harmony, and respect differences in belief according to the ancestral recommendations. Kinship is a Dayak Halong culture that they still care to build social integration.
\end{abstract}

Keywords - Interfaith Relations, Social Integration, and Dayak Halong Communities

\section{INTRODUCTION}

Multiculturalism has always been actual to be discussed even as a recommendation from the government. Multiculturalism is defined by Prasudi Suparlan as an ideology to treat diversity, diversity and equality. Multiculturalism can be established with the capital of cultural diversity, a religion owned by plural ethnicities. In a sense, the concept of multiculturalism cannot be equated with plural society, but developed from a plural society. In multicultural weaving that may be a constraint of which is a religious issue, as Huntington puts it in the clash of civilizations [1]. Whereas in each religion contains guidelines for human interaction and interact with God.

The problem of many religious relations is also discussed by many people and social science experts, especially when there is religious feud in this part of the country. The works are based on 2 views of the mind known as the model. The two views of this model are based on the nature and character of each model as used by J. Pieter and J. Titaly, i.e. soft encounters and hard encounters [2].

The perspective of soft encounters may be based on cultural and historical perspectives on deliberation and consensus. Cultural deliberation and consensus is a cultural fact that is owned by all ethnic groups in the country united by politics into the nation of Indonesia. Political unity by Suparlan is called the national system [3]. Each ethnic group has a stereotype of the results of its historical experience when interacting with other ethnicities. This statement informs that the Indonesian nation is a new nation compared to other ethnic groups in the archipelago.

Historical records inform, that ethnics in the archipelago in the past many develop themselves by building ethnic kingdoms (ethnic-state). The kingdoms are based on Hinduism and Buddhism, and the sultanates with Muslim as their official religion. The entry of Hinduism, Buddhism and Muslim became a state religion not through a military expansion but with a soft meeting. None of the kingdoms in the archipelago are involved in a palagan sparked by religious issues. If there is an inter-royal conflict only a matter of grabbing hegemony and succession. Similarly, when the nation is formed with the ideology of the country Pancasila, the process of making is the result of deliberation and consensus to protect all religions embraced by the Indonesian Nation. It is also interesting that Banjar ethnic ideas are often used to end the conflict by way of badapat or islah. Life together lives in a longhouse for Dayak ethnic, known as Betang in Central Kalimantan, lamin in East Kalimantan, House of Panjae designation for Dayak Iban people to name their long house. Long house for the Dayak people is the center of their culture which is also a symbol of the intimacy of relationships among fellow relatives.

Another encounter, when there was a religious conflict in the Kei Islands at the end of XX century precisely 1999. The people of Kei know the culture called as shib is a traditional promise to help each other inter-religion. The concept of shib is operated by the society when the bloody religious chaos occurs in Watran and Uwat, when Catholics run forests to avoid conflict protected by Muslims, the opposite of Muslims is protected in the church by Catholics [2].

The point of view of hard meetings seems to be based on the history of the struggle of Muslim and Christianity. This view is based on the existence of the Crusades. The Muslimic Sultanate's resistance to the Western powers that graced the history of Indonesia in the period of the sixteenth to the nineteenth centuries, coupled with the rural social movements 
that waged jihad and sabil ideologies in the late nineteenth century. Religious conflicts occur in Ambon and Poso.

The two views above show each other opposing each other. These two views are constituted by structural and functional traditions in anthropology in observing people in a rural area. This paper will discuss religious relations and social integration in Dayak Halong community in Halong of Balangan, South Kalimantan Province. Interaction between Kaharingan, Hindu, Buddhist, Christian and Muslimic religions in Dayak Halong community runs in balance and unwittingly has built a multicultural atmosphere in a village very far away with the capital of this country. So the model in writing tends to think soft encounter.

Dayak Halong community in this paper is positioned as a subject that thinks, acts, maintains and develops traditions and steps for harmony in its social relations. According to Dayak Halong way of thinking in maintaining social harmony then the problem in this research is how they develop social relation of their fellow both fellow religion and with different religion?

From the problems raised in writing, we assume that the Dayak Halong Communities, social ties are built by geneological factors that make it easier for them to interact with relatives despite different religions. The good impact of social ties encourages social integration within the Dayak Halong communitiy.

\section{METHOD}

Acquisition of data in writing begins when visiting the annual Dayak Halong festival in April 2017 held in Halong, precisely in Kapul Village. In the middle of the year precisely in August 2017 observations were made, thus finding important clues about the religious adaptation of religions adopted by the Dayak Halong community towards religious relations. Interviews conducted in this study were interviews with Mr. Ponidi (August 2017), interviews with Mr. Awa (August 2017), and interviews with Mrs. Arisma (August 2017)

The kinship of the Dayak Halong community is an indication of the building of interfaith relations and social integration. In August the study was carried out by developing a thesis is adopted from a model developed by Fedyani [4], becoming a Dayak Halong social integration a unique social relations implication, and an internal process of adaptation to interreligious relations. This research uses qualitative approach with observation technique, interview and literature.

\section{RESUlT AND Discussion}

The Dayak Halong communiy settle on customary territory, which is located in Halong Sub-district. Dayak Halong are categorized, including a large group of Dayak Ngaju. The large groups of Dayak people is offered by Michal Dove as quoted by Arman [5], which also cites the opinions of previous experts, that Dayak ethnics viewed from culture, language and geographically divided into three major groups, i.e. (a) north group, included Dusun and Murut, (b) southern groups, including Ngaju, and (c) Middle groups, including Kenyah, Kayan, Kayang and Iban.

Based on Dove, the grouping of Dayak then Dayak Halong belongs to the Southern group, which there is a large group of Dayak Ngaju. Dayak Ngaju as a large group used as a reference to see the mother of Dayak Halong. Based on records from Beeckman who visited Southeast Kalimantan in 1714 on a trade mission arrived in Banjarmassen (Banjarmasin). Arriving in Banjarmasin, Beeckman is quoted by Victor T. King, divides the indigenous community into two groups, namely the Muslim coastal Banjar people who are physically proportional and clean bodies, and pagan Byajos people who live in the interior [6]. The outback has a taller, stronger, braver body than the Banjar and the language it uses is different from that used by Banjars [6], [7]. Assessment of Beeckman the author used in general to distinguish physically between Banjar ethnic and ethnic hinterland which he called Byajos people who are none other than Ngaju people. Dayak Halong people call themselves Dayak Halong because they live in an area called Halong. Family of Dayak Halong community likes most other Dayak tangible family of batih and extended family so that the kinship is formed. They are very respectful and appreciative of people who visit his village. Some of them are farmers, like most Dayaks generally.

The Dayak Halong settlement is spread over 10 villages: Kapul Village, Binuang Santang Village, Mauya Village, Mantuyan Village, Tabuan Village, Hauwai Village, Liyu Village, Aniungan Village, Buntu Pilanduk Village and Marajai Village [8]. Like most Dayak ethnic, Dayak Halong community is mostly religious ancestor that is Kaharingan religion, some embraced Buddhism, Hinduism, Christianity, and Muslim. The existence of places of worship such as traditional halls, monasteries, churches and mosque is an artifact as a reinforcement of the existence of religions. The diversity of religions seems to reinforce the notion that open cultivators are more open than the people living from hunting and gathering. The diversity of religions adopted and cared for interreligious relations implies that the Dayak Halong community is an open community while maintaining its tribal identity. The social life is no longer united in a longhouse, but has moved to individual homes.

Kaharingan religion for Dayak Halong can be said as the heir of ancestral religion. Religion in general can be interpreted belief in the power of superhuman that can protect and give blessing to his followers. Faith in religion is inflated by rituals as a denial of human potential that tends to claim to be the creator. In other words ritual is the submission of man to super human power (God). Dayak Halong people are always grateful to God and not forget the ancestral spirits for their success in farming (huma) or success in other fields, i.e. Aruh Membatur and Aruh Baharin. Aruh membatur is a ritual of honor aimed at families who have died. Aruh Baharin is a ritual of gratitude for the success of their harvest. Aruh Baharin is organized by a large family collaboration that typically consists of 25 to 30 family families respecting families. 
Kapul Village as Dayak Halong lives is used as the research area for this paper. Kapul Village area of $19.00 \mathrm{~km}^{2}$ is chosen, because the local government made a cultural village of Dayak Kapul community. A monastery called Dharma Ratana was inaugurated in 1989. Times may pass, but tradition as their identity as Dayak people is still preserved. In order to celebrate the anniversary of Balangan District was chosen to be named Festival, Ngetan Adat Leluhur Amak Nyembelun, which means remembering the ancestral custom to build Вапиа (village). Festivals always complained of race of crush, bagasing, engrang, craft Halong and so forth. Kapul Village has 4 of Neighborhood Association (Rukun Tetangga). Kapul Village has one of Kindergarten, one of Al Quran of education (Taman Pendidikan Alquran), and Elementary School, one of Integrated Health Service Center (Posyandu) and one of Villages Service Centre (Poskesdes). Interestingly there are 3 churches, a monastery of a traditional hall, a mosque. The people jobs are civil servants, farmers, rubber farmers and other entrepreneurs [8].

\section{A. Social Relations and Adaptation}

Aligning the above narrative, this article examines the Dayak Halong social intregration in its equal or good social relations and downs (vertical). Social relations in religious relations are adaptive so that social integration is fostered. The process of adaptation between religions with local religion informally lasted long enough through the kinship path. Kinship by Fedyani is closely related to biological and sociocultural thought [9].

The social relations are constructed through religion, beginning with a long adaptation, thus strengthening kinship and its inward orientation that strengthens the identity. Let's just say, social relationships between different ethnic signs and symbols that are selected and operated by the actors are very dependent on the type of purpose in the current interaction situation. Social relations with such a model manifest in the form of friendship and marriage.

Borrowing Fedyani's opinion [4] about the two patterns of social relationships are the horizontal patterns of relatives and not relatives; and vertical patterns are not relatives of one another interconnected hooks. The reason for these two patterns is used based on the intricacies and inter-religious interactions; and Dayak Halong community does not close itself from the enormous physical and social environment.

\section{B. Parallel Relations (Horizontal) and Vertical Relation}

A parallel or horizontal social relation is characterized by the low socioeconomic predicates of the Dayak Halong community members in Kapul Village. Social relations are observed are two households that have the status title of work, kinship, occupation, neighbors, education, and can also ethnic.

Particular social relation is observed as the household of Mr. Awa as Dayak Halong Buddhist and Mr. Ponidi as Dayak Halong Muslim. Both of people come from Kapul Village and work as farmers' fields commonly known as cultivators. $\mathrm{Mr}$
Awa's is name of most Dayak people who consist of only one word, while the name Mr. Ponidi is a name commonly used by most Javanese when he is a Dayak Halong. Economically a farmer is considered as a small farmer, but he cares about education for his children. How many of their opinions, in numerical terms he did not answer, simply answered enough to live and to go to school for his children. Mr. Ponidi has one child in Senior High School, and two childreen in elementary school. Mr. Awa has 4 children each still in high school, junior high school and elementary school.

Dayak people as Mr. Awa and Mr. Ponidi always visit each other, although both are different religions, but they have feeling a family as Dayak Halong People. The respondent are always involved in helping ritual activities of Dayak Halong people who are Kaharingan religion, aruh membatur and aruh baharin. The mutual cooperation event for the cleanliness of their village is always actively involved. They also visit each other on their respective religious holidays and weddings, so also their involvement in helping national events such as Independence Day of the Republic of Indonesia.

According to Mr. Awa, Buddhism has long been embraced by the Dayak Halong community without mentioning the number of years. Mr. Awa assumes that his grandfather and father are Buddhists, so he feels Buddhist, his roots as Dayak Halong people are not deprived. He also argues in the Buddhist ritual, there is a culture burning hio similar to Kaharingan ritual. Mr. Awa considers that Kaharingan and Buddhist religions advocate harmony in ordering the world. That nature must be well preserved, so also the relationship with the social environment must be treated with compassion. Mr. Akhmad thinks that although he is a Muslim, he still holds the title of Dayak Halong. There is a common belief that if a Dayak person in South Kalimantan after entering as a Muslim, then he is babarasih (clean up) as a Banjar people. $\mathrm{Mr}$ Ponidi's opinion suggests, about the pride of his identity as a Dayak, even though he is Muslim. As a Muslim, he sees harmony, social and environmental concerns carried out by relatives of Kaharingan who are similar to Muslim religion. $\mathrm{He}$ also saw that the mambatur and baharian (mutual cooperation) are part of keeping the togetherness of the people in Kapul Village.

The relationship between Mr Ponidi and Mr Awa provides information that interreligious relations are based on their identity as Dayak Halong people, who promotes togetherness, even though their religion is different. Emotional closeness raises a collective awareness, even though different religions are part of a kinship system that is still intact for the Dayak Halong community.

In contrast to the horizontal relationship exemplified above a vertical relationship is also found in this observation. The involvement of the parties in this relationship has inequality and status in the social ladder. Actors involved in vertical relationships can be insiders as well as immigrants, but they have formal positions in government or predicate in religion.

Prior to 1986, Buddhism in Kapul Village by many common people was known as Buddhist-Kaharingan religion. At that time the government did not recognize Kaharingan as 
a religion but a belief. The abrogation of the Kaharingan title behind the word Buddha can be said to be a part of a Buddhist teacher named Mr. Ponidi. Mr. Ponidi came from Blitar East Java, he was brought to Halong especially Kapul Village in 1986 to teach Buddhism for his adherents in the village. $\mathrm{Mr}$ Ponidi successfully believes the adherents, so that the title of Buddhism does not need to be added with the word Kaharingan become Buddha Darma. Moreover, the arrival of Bhiku Chita Santo from Banjarmasin to Halong specifically to Kapul Village to teach and broadcast Buddhism has received a good response. Even Bhiko Chita Sato is supported by the community and the apparatus is managed to make 3 pieces of monastery, one of which is in the village Kapul monastery named Dharmaratana as the grandest among the temples in Halong. The inauguration of the monastery in 1989 at the time of Kapul Village is led by Mr. Kurnaini.

Hierarchically in the structure of the Buddhist broadcaster Mr. Poni is under Bhante Karuna Viro is a Buddhist monk. Bhante or monk as a Buddhist priest gets his predicate through a long process. His identity as a bhante or monk is marked by the cloak he uses and blows his head. He also obtains permission from Balian (religious cleric Kaharingan), muslim religious leaders and pastors of Christianity. To be more legitimate, Mr. Ponidi also asked for permission from the village head. Mr. Ponidi was lucky his idea to remove the word kaharingan behind Buddhism was responded well by the village head, i.e Mr. Kurnaini from Semarang. Legally, the village head officially moves on to the higher level, namely the sub-district head.

The Dayak Halong community specifically Kapul Village accept the idea of the disappearance of the word Kaharingan behind the Buddhist name. Acceptance of this idea is based on kinship ties, mutual understanding, and does not question the issue of different beliefs in order to maintain group solidarity. Under the terms of both official and unofficial agreement, the word Kaharingan behind the word Budha is omitted. The existence of bhante or monk Karuna Viro and the inauguration of 3 monasteries in Halong by head of Balangan District is a symbol of official government recognition about the name of Buddhism without being accompanied by Kaharingan.

The above phenomenon provides information on the particular social relationships between religious leaders, roles, and officials to gain recognition about Buddhism in Halong, especially in Kapul Village without conflict. This scene is a social fact of group solidarity supported by the government.

\section{Social Integration}

Social integration in Kapul Village is the aruh membatur, bahuh baharin, and the annual festival of Indigenous of Ngetan Adat Leluhur Anak Nyembelun Banua. Aruh Membatur is a Kaharingan religious ritual as the ancestral religion of Dayak Halong People. This ritual is a form of respect for Dayak Halong people for their families who have died. Implementation of the usual arranging aruh held for 4 days and 4 nights. In the procession it usually slaughters the sacrificial goats to commemorate the 100 days and the buffalo to commemorate the 1000 days.
Aruh Baharin is also a part of the Kaharingan religion's ritual of expressing gratitude for the harvest and other successes. This ritual procession is held in the hall (commonly used for worship). The ritual is led by 8 people of balian (religious Kaharingan religion). This ritual became more sacred, when the balians are summoned the spirits of the ancestors together to enjoy the offerings. This ritual peak event falls on the sixth night, when the balian perform a dance ritual (batandik) in a trance state accompanied by a hammering of a gong.

The two rituals above, the preparation involved also the Dayak Halong people who are Buddhists, Muslims, Christians, and Hindus, as such, the confession of Mrs. Arisma as a Hindu teacher. Their involvement is a reflection of their identity as Dayak, who always maintain the harmony of the cosmos. They still feel that the inner cosmos harmony including the physical and social environment must be maintained and cared for. Gertz is the founder of the symbolism-interpretative approach as quoted by Fedyani [10], that the aspects of primordial culture is as an old element at a certain stage still survive. The ritual of aruh membah and aruh baharin is a manifestation of the expression of gratitude to God against all the material they obtain. Borrowing Soyomukti's view, that the non-material world and matter are woven into one unity for the harmonious and solider that leads to a loving civilization [11].

Annual Festival of Ngetan Adat Leluhur Amak Nyembelun, which means mutual religious of tolerance, considering the ancestral customs to build banua (area) is part of Balangan District birthday celebration. The idea of the festival was inspired by the harmony of religious life in the Halong Community and local government in the form of ritual agenda of Balangan. Social integration is rooted in Dayak Halong society, not created by the Government. Balangan government requires the building of social unity supported by the cultural spirit of Dayak Halong community. Cultural spirit harmony is between the physical environment, social environment can be treated by respecting the religion held by the citizens.

\section{CONCLUSION}

Social integration occured in society is awakened by a feeling of primordial identity as Dayak Halong People. Admittedly the longhouse culture is not there, but fostering group solidarity is a force of solidarity passed down through the generations by their ancestors.

Their different religious presence in Kaharingan religious rituals is a manifestation of the old religious presence in a new culture. Dayak Halong people are in a state of transition to a multicultural society.

Local government as a patron of the Dayak Halong government is the awareness of pride of primordial identity. Religious diversity is a wonderful way to be loved of God by organizing annual rituals in the form of festivals.

tread the path to multicultural can be studied from the awareness of the identity of the nation. inter-religious relationships can build the integration of the nation 


\section{REFERENCES}

[1] P.S. Huntington. Benturan Antar Peradaban, terjemahan Sadat Ismail. Yogyakarta: CV. Qalam.

[2] P. Jeneman, A. T. John. Hubungan Antar Agama dalam Kebhinekaan Indonesia (Studi Kasus Terhadap Hubungan Warga Jemaat GPIB Tamansari Pospel Kalimangli dengan Warga Muslim di Dusun Kalimangli), e-journal UKSW, 2017.

[3] S. Parsudi, Suku Bangsa dan Hubugan Suku Bangsa. Jakarta: Yayasan Pengembangan Kajian Ilmu Kepolisian, 2005.

[4] S.A. Fedyani. Integrasi Sosial Golongan Miskin di Perkotaan: Kajian Kasus di Jakarta. Jurnal Antropologi Indonesia, vol. 29, No 3, 2005.

[5] S. Arman, Analisa Budaya Manusia Dayak" dalam Paulus Florus (dkk), Kebudayaan Dayak Aktualisasi dan Transformasi. Jakarta: PT. Grasindo,1994.

[6] King T. Victor, Kalimantan Tempo Doeloe, terjemahan Ratih Widyaningrum. Jakarta: Komunitas Bambu, 2013.

[7] D. Beeckman. A Voyage to and From the Island of Borneo in the EastIndies. London: T. Warner and J. Atley, 1718.

[8] BPS Kec. Halong. Kecamatan Halong dalam Angka. 2014.

[9] S.A. Fedyani. Logika Antropologi Suatu Percakapan (Imajiner) Mengenai Dasar Paradigma. Jakarta: Prenadamedia Group, 2015.

[10] S.A. Fedyani, Konflik, dan Integrasi Perbedaan Faham dalam Agama Muslim. Jakarta: Rajawali, 1986.

[11] S. Nurani, Pengantar Sosiologi, Joyakarta: Ar- Ruzz Media, 2010 